Ilmenau University of Technology

Institute of Economics

Ilmenau Economics Discussion Papers, No. 110

Market-internal Financial Regulation in Sports as an Anticompetitive Institution

Oliver Budzinski

October 2017

Institute of Economics

Ehrenbergstraße 29

Ernst-Abbe-Zentrum

D-98 684 Ilmenau

Phone 03677/69-4030/-4032

Fax 03677/69-4203

http://www.wirtschaft.tu-ilmenau.de

ISSN 0949-3859 
Market-internal Financial Regulation in Sports as an Anticompetitive Institution

\section{Oliver Budzinski*}

Abstract: Financial regulation in sports is usually discussed in the context of representing an instrument against "financial doping". Notwithstanding the merits of this discussion, this paper takes the opposite perspective and analyses how market-internal financial regulation itself may anticompetitively influence sporting results. Virtually every regulative financial intervention distorts sporting competition to some extent and creates beneficiaries and losers. Sometimes, the actual winners and losers of financial regulation stand in line with the (legitimate) goals of the regulation like limiting financial imbalances or preventing distortive midseason insolvencies of teams. However, financial regulation may also display unintended side-effects like protecting hitherto successful teams from new challengers, cementing the competitive order, creating foreclosure and entry barriers, or serving vested interests of powerful parties. All of these effects may also be hidden agendas by those who are implementing and enforcing market-internal financial regulation or influencing it. This paper analyses various types of budget caps (including salary caps) with respect to potentially anticompetitive effects. UEFA's so-called Financial Fair Play Regulations are highlighted as an example. Furthermore, the paper discusses allocation schemes of common revenues (like from the collective sale of broadcasting rights) as another area of financial regulation with potentially anticompetitive effects. Eventually, the effects of standards for accounting, financial management, and auditing are discussed.

Keywords: sports economics, financial regulation, budget caps, salary caps, financial fair play, financial doping, collective sale of media rights, sports broadcasting rights, revenue sharing

JEL-Codes: Z20, Z23, L40, L83, K21

\footnotetext{
* Professor of Economic Theory, Institute of Economics, Institute of Media and Mobile Communication, Ilmenau University of Technology, Germany, email: oliver.budzinski@tuilmenau.de. The author thanks Annika Stöhr and Milan Lange for valuable editorial assistance. A revised version is forthcoming in the Palgrave Handbook on the Economics of Manipulation in Professional Sports.
} 


\section{The Role of Financial Regulation in Professional Sports}

Imbalanced financial means among competitors in a sports league or championship are an evergreen in sports economics as well as in sports policy (see for more details Schubert \& Hamil 2017). The main concern is that financial imbalances lead to an uneven playing field where some competitors have better chances to win than others from the outset on. The notion of a team buying success is often an unpopular one in sports, even in professional and commercial sports. It seems to violate values of integrity and fairness of sporting competitions. How can it be in line with the ideals of sporting competition if Paris St. Germain with a budget of about $€ 550$ million - and being able to pay more than $€ 200$ million for just one player (Neymar) - competes against SC Amiens (with a budget of ca. $€ 25$ million) in the premier football league of France? How can better talent play a role when Sebastian Vettel races in an approx. $€ 380$ million-budget Ferrari against Kevin Magnussen in a roughly $€ 115$ million-budget Haas in Formula One? The underlying notion of the unfair character of such financial imbalances is well expressed in the recently popular term of financial doping (Gammelsæter \& Senaux 2011; Morrow 2011; Könecke \& Schubert 2014; Schubert \& Könecke 2015; Schubert \& Hamil 2017).

On the other hand, financial imbalances are also a direct consequence of success in sports competition. Traditionally, the more successful team often directly earns a monetary-valuable price. More importantly, more success increases the probability of becoming popular with the fans (the consumers). This leads to more income from ticket sales, the sale of merchandise as well as the sale of media rights like broadcasting. Furthermore, the attractiveness for sponsors increases, generating more income from this side as well. In other words, even if all teams of a league start with the same budget, differences in performance will lead to differences in budgets and financial means. How can it be fair, if these hard earned financial advantages are taken away by regulation? Wouldn't that imply an unfair advantage for the worse performing team, for the lesser talent?

In reality, however, there is no level-playing-field starting point in professional sports. There have always been 'external' financial injections - be it through 
wealthy fans, overly-generous sponsorships, eager local politicians, local companies or other ways (see the examples from Schubert \& Hamil 2017). Motives can differ a lot, sporting enthusiasm, local patriotism and loyalty, power over a famous toy, prestige and fame, reputation of individuals and brands, etc. The ability to acquire such 'external' financial injections may be independent from sporting success and talent to some degree and partly accidental. Moreover, the delineation of internal, 'earned', financial means and external, 'not earned', financial injections is blurry and ambiguous. A donation can be a fan enthusiastically desiring to help his club or a wealthy business man looking for a new toy. Sponsorship money can be a sharp calculated advertising effort or motivated by local patriotism and loyalty - or even driven by empire building desires of managers. Taxpayer money can be injected to promote the local sports culture and competitiveness as well as the local economy and tourism - or to please sports fans and influential locals in order to maximize votes at the next election. Why should one motive to invest money into sports be allowed and 'fair' and the other not? How shall one reliably discriminate between different motives for investment? Shouldn't this be done for motives of sports club members and buyers of sports club stocks as well?

Things get even more complex if the inherent dynamics are considered (economies of sporting success). Due to a self-reinforcing effect of success and revenue increases - more budget due to sporting success in $t_{1}$ may lead to higher winning probability in $t_{2}$ implying more revenues for $t_{3}$, etc. - the inherent imbalances from the sporting dynamics may be substantial. Even if all revenues are deserved through past sporting success, they still can lead to a situation where the now rich club can lay back and rely on its superior financial power to stay at the top without current superior skills or talents. Ironically, poorer teams may now need an 'external', 'not earned', financial injection just to be able to compete with the rich team again - and be able to showcase current skills and talents.

Notwithstanding, there is no systematic market failure in professional and commercial sports leagues (or other championship types) that would unconditionally require financial regulation. First, the connection between budget and success is neither immediate nor always prevalent. However, if there was no connection at all, the financial doping discussion would be irrelevant. But it is an 
imperfect relation; the highest budget does not always win. The recurring lack of success of VW-sponsored VfL Wolfsburg in German Bundesliga or Toyota in Formula One (2002-2009) - in both cases despite their budgets being among the highest - represent examples. Second, the connection between success and popularity (and thus between success and income) may be confused by external popularity factors pushing fan demand (local patriotism, same social class image, superstar effects, sympathy, tradition built upon distant past success, media coverage, boulevard media presence, etc.; Budzinski \& Pannicke 2017). These factors may be less important in sports than in other entertainment industries but they are still there. In European premier football leagues, between 49.3 (English Premier League) and 72.1 (German Bundesliga) per cent of the revenues of the teams come from sources like ticket sales, hospitality, merchandise, sponsoring and advertising, sale of players, and other commercial activities (Budzinski 2017a). All these revenues are only imperfectly connected to success and regularly teams in lower positions (or even in lower leagues) earn more from these revenue categories than some of their higher placed competitors. This also illustrates that sports leagues neither represent fitting examples for Akerlof-type rat races, nor for strict positional competition (see for details Budzinski 2014, 2017a). Neither do revenues directly and inevitably depend on the ranking position, nor are there incentives to produce unproductive signals. Furthermore, the additional effort is not waste and the "prize" (the revenues) the teams are competing for is very dynamically increasing. Actually, it requires a special type of financial regulation to create a position-dependency of some revenues - namely, the collectively collected media revenues (see section 3 ). ${ }^{1}$

Despite the absence of market failure, there may be economic reasons for financial regulation, like adverse incentives and moral hazard problems fuelled by bail-out expectations in the case of running insolvent if the teams/clubs are sufficiently prominent (too prominent to fail, Budzinski 2014: 88-90; soft budget constraints,

\footnotetext{
${ }^{1}$ While between 50.7 (English Premier League) and 27.9 (German Bundesliga) per cent of the revenues are generated from the collective sale of broadcasting rights, the existence of strict position-dependency revenues require a specific type of distribution of these revenues (see section 3), which, strictly speaking, does currently not exist in these leagues (Budzinski \& Müller-Kock 2017: 11-12).
} 
Andreff 2007; Storm \& Nielsen 2012). From an economic perspective, this is particularly worrying if taxpayer money is used to bail-out badly-managed teams (zombie races; Franck 2014). Often, however, financial regulation is motivated by fairness considerations or by the goal to make sporting competition closer (competitive balance considerations; see also section 3).

In sports markets, financial regulation typically takes the shape of a market-internal institution, implemented and enforced by a market-internal regulator (see for more details Budzinski \& Szymanski 2015; Budzinski 2017b). This type of regulation is not government regulation. Instead, the market participants give themselves rules and create a body (some type of sports association ${ }^{2}$ ) to govern these rules. While this is highly unusual for 'ordinary' textbook markets, it follows the fundamental sports economic logic that competitors in a sports market must cooperate on the rules of the game (Rottenberg 1956; Neale 1964). Naturally, once a market-internal regulator exists, it enjoys market power (more or less depending on the institutional structure; Budzinski \& Szymanski 2015) and may extent its governance beyond the necessary rules of the game and into commercial activities. Furthermore, principal-agent-problems may create room for the market-internal regulator to pursue other goals than the benefit of the (league or championship) participants or the sports in question. Consequently, real-world financial regulation may indeed be motivated by the desire to protect the integrity of the sport. However, it may also be motivated by underlying goals and agendas that serve partial interests of some stakeholders or the self-interest of the governing sports association. $^{3}$

Altogether, the topic of financial imbalances and financial regulation in sports is a difficult one. Disentangling sportingly-deserved income advantages from

\footnotetext{
${ }^{2}$ Examples include such diverse organizations as, inter alia, the Fédération Internationale de Football Association (FIFA), the International Olympic Committe (IOC), the National Football League (NFL), the International Association of Athletics Federations (IAAF), the Union des Associations Européennes de Football (UEFA), the United States Soccer Federation (USSF), the Niedersächsischer Judoverband (NJV), or the Fédération Internationale de l'Automobile (FIA).

${ }^{3}$ Budzinski \& Müller-Kock (2017) discuss an interesting case where financial regulation serves as a means to secure and exploit the market power of a sports promoter and to stabilize an anticompetitive cartel. This example represents an extreme case showcasing how manipulative to the sporting outcome financial regulation can be.
} 
sportingly-not-deserved revenues is an ambitious task and perhaps a mission impossible (see the discussion on UEFA's Financial Fair Play in section 2). Both financial imbalances and financial balance may be viewed to be unfair and against the spirit of sports as the discussion so far has demonstrated. In this chapter, the second view is in the core of the reasoning: financial antidoping may actually itself manipulate results and restrict competition. ${ }^{4}$ Section 2 analyses various types of budget caps and their possible restrictive effects on competition. Section 3 addresses an often overlooked element of effectively financial regulation, namely the distribution of common revenues and the re-distribution of competitors' income through market-internal regulation. Eventually, section 4 very briefly discusses accounting standards as financial regulation before section 5 concludes.

\section{Budget Caps}

\subsection{Types of Budget Caps}

Direct financial regulation takes the shape of various forms of budget caps. The concept of a cap is to define a maximum monetary ceiling, for instance, for a class of expenditures.

- A global budget cap covers all types of expenditures of a team, whereas a partial budget cap only limits spending of a specific class of expenditures (e.g. salary caps for players, transfer payment caps, or an engine development freeze like in some types of motor racing where the expenditures on improving the engine are capped).

- An absolute or symmetric cap limits all budgets to the same nominal amount, whereas a relative or asymmetric cap prescribes different maximum budget volumes to different teams.

- A static budget cap defines the maximum spending, whereas a dynamic cap limits the growth rate of the budget.

\footnotetext{
${ }^{4}$ For the first view see with a comprehensive literature review Schubert \& Hamil (2017).
} 
- Budget caps can also regulate income instead of expenditures. A universal cap limits a total income or revenue measure of a team, whereas a discriminatory cap only limits income or revenue from defined sources.

Obviously, different types can be combined. A general problem with all types of budget caps is evasive actions by the regulated teams - either as creative exploitation of loopholes or as outright illegal conduct. These evasions of regulation may difficult to detect and/or hard to police due to asymmetric information, enforcement power deficits or other various reasons. If budget caps are imperfectly enforced, a distortion of sporting competition surfaces because now the most creative and sophisticated cheaters enjoy a competitive advantage. This stands hardly in line with the integrity of the sport. In reality, many budget caps will fall short of being sufficiently enforceable. Notwithstanding, for the sake of the argument, I assume perfectly enforceable caps in the next section.

\subsection{Distortive Effects of Budget Caps on Sporting Competition}

All types of budget caps change the market allocation of budgets and as such distort competition in comparison to the market result. For instance, an absolute global budget cap sets a ceiling to total expenditures $\left(B_{c}\right)$. For teams $i$ with a budget $\mathrm{Bi}$, for which $\mathrm{B}_{\mathrm{i}}>\mathrm{B}_{\mathrm{c}}$ the cap entails a competitive disadvantage (= there financial competitive advantage is eroded), whereas teams with $B_{i}<B_{c}$ benefit because their budget disadvantage is reduced. The distortive effect compared to a free market situation increases with $\left|B_{i}-B_{c}\right|$. Of course, this distortive effect may exactly be the goal of the financial regulation since it effectively reduces the spread among the budgets and levels the financial playing field. If even the natural budget of the poorest team would exceed the cap, then the regulation enforces financial equality. In the latter case, the parameter of competition "acquiring financial means" is effectively and completely eroded. While being a rather radical instrument, absolute global caps create comparatively few anticompetitive effects. They merely devaluate one dimension of competition in a multidimensional contest.

Partial budget caps are similar to global caps if the capped expenditure class is the dominant parameter of competition, like with salary caps for player wages in ball 
team sports. ${ }^{5}$ However, if competition is significantly multidimensional, for instance, when competition on equipment and technology plays an important role (skiing equipment, swimsuits, technology in motor racing, etc.), shifting effects occur. Richer teams will keep spending more in this scenario than poorer teams but they will shift their expenditures to non-capped classes. For instance, when a motor racing series introduces a cap on spending for engine development (engine development freeze) like Formula One did a couple of years ago, high-budget teams will not stop spending their higher financial means. Instead, they will shift their expenditures to chassis development, aerodynamics improvement, or driver and engineer wages, for instance. Possible effects (depending on the specific design of the partial cap) may include, inter alia,

- competitive disadvantages for those teams that were lagging behind in the capped area at the time of the cap introduction because they are now stuck with an inferior technology/equipment and cannot invest to catch up.

- competitive advantages for those who specialized in the non-capped area because now this parameter of competition plays an increasing role.

- counter-intuitively also competitive disadvantages for those not-so-rich teams who specialized in the non-capped area because now all the money from the rich teams is thrown at this area of development/competition and efficiency of money use becomes less paramount here as does niche competence/specialisation.

Already from these sketches it becomes clear that the effects of partial caps are rather ambiguous and depending on the specific design. At the same time, the effects on the competitive order are not neutral at all. Some sporting-relevant competences become devalued, other appreciate, creating non-trivial distorting effects on competition.

Relative/asymmetric caps are very directly of anticompetitive concern because they cement inequality. That some teams are allowed to spend more than others by regulation appears to be at odds with most fairness notions from the outset on. Still, there is the example of Financial Fair Play that is briefly discussed below. In the

\footnotetext{
${ }^{5}$ See on the analysis of salary caps in team sports, inter alia, Diet/ et al. $(2011,2012)$.
} 
shape of freezing current budgets (perhaps to prevent ruinous budget wars), asymmetric caps cement the competitive order at the time of their introduction and prevent poorer teams from catching-up investments, thus protecting competitive advantages of the rich teams like market power rents. In general, asymmetric caps artificially cement or create financial inequality.

Whether budget caps are static or dynamic does not change the effects of symmetric, global or partial caps (but dynamic caps may align a control of spending behaviour with a growing market, i.e. increasing revenues). Dynamic asymmetric caps, however, may increase the inherent artificial inequality of asymmetric caps compared to static ones. If the cap addresses income or revenue figures instead of expenditures, the effects on sporting competition do not change considerably. Capping total income implies that you cannot spend more than the cap volume (provided that financing through liabilities is included in total income). A discriminatory income cap, i.e. a cap on defined sources of income or revenue, does have distorting effects on sporting competition if teams have different strengths in different income/revenue categories. Those teams who are either strong in the capped category or need to rely on it because they can substitute income/revenue sources suffer competitive disadvantages in favour of those who are comparatively stronger in the non-capped sources. Adding asymmetry and dynamics aggravates the anticompetitive effects.

\subsection{The Example of UEFA Financial Fair Play}

In order to illustrate the possible distorting effects on sporting competition from financial regulation (or financial antidoping), I follow Schubert \& Hamil (2017) and address a prime example of complex and ambitious regulation - UEFA's Financial Fair Play (FFP) regulations (see for detailed descriptions and discussions, inter alia, Vöpel 2011; Budzinski 2014; Franck 2014, 2016; Maxcy 2014; Peeters \& Szymanski 2014, 2015; Preuss et al. 2014; Szymanski 2014; Madden 2015; Sass 2016; Schubert et al. 2016). It represents a rare example of an asymmetric/relative budget cap combined with a discriminatory cap on certain revenue types. Obvious from the name of the regulation, financial fairness is the prime target and the integrity of sports plays a prominent role in its justification. 
More precisely, it is one element of the overall FFP regulations that triggers the budget cap effect, namely the so-called break-even rule (originally from 2010; latest version: UEFA 2015): relevant expenses must not exceed relevant income (with an acceptable deviation of up to $€ 5$ million over three financial years ${ }^{6}$ ). Thus, the budget of any given team is capped by the relevant income it can create. This constitutes an asymmetric budget cap since the relevant income differs among clubs. A team that has earned more money is allowed to spend more than a competitor with less relevant income, i.e. a 'richer' team is allowed to spend more than a 'poorer' team.

The UEFA defines relevant income in great details. Somewhat simplified, it includes direct football-playing revenues (like sales of tickets, beverages \& food during the games and media rights, UEFA price money, or player transfer profit), sponsorship and advertising revenues, government subsidies and grants, and indirectly footballor brand-related revenues (like merchandise or commercial activities exploiting the clubs' brand as well as lottery revenues). Many of these 'relevant' income sources rest upon the brand value and popularity of a team and/or past success. For instance, Real Madrid enjoys significantly more income from media rights, sponsorship, advertising, merchandise, or brand exploitation than FC Copenhagen (FC København; FCK) - irrespective of current management talent. Moreover, many of these categories will not respond quickly to sporting success. In other words, even if FCK sensationally wins the UEFA Champions League, Real Madrid's income from most of these sources will remain significantly higher than those of FCK for a considerable period of time. This implies that FCK will be restricted by UEFAs budget cap to spend significantly less than Real Madrid irrespective of sporting success (and management talent)! In itself, this will drastically reduce the probability of FCK continuing to beat Real Madrid. Real Madrid is, in effect, protected by FFP from getting its market leading position challenged by FCK on the basis of (management, playing, other) talent and skills alone.

In other words, UEFA FFP regulations prevent less famous but talented teams (the newcomers) to close the financial gap to the famous frontrunners at the time of

\footnotetext{
${ }^{6}$ See for more details on exceptions and acceptable deviations UEFA (2015).
} 
FFP introduction (the incumbents). The asymmetric budget cap cements the financial unlevel-playing field and blocks poorer clubs from challenging richer clubs on talent. As such, the asymmetric budget cap creates a relevant anticompetitive effect: it contributes to cementing the competitive order and protects the incumbents from talent-based competitive challenges. In a way, the budget cap crates an entry barrier to the premier market segment in European football. While this takes place under the label "financial fair play", it certainly can be questioned how "fair" this actually is. UEFA's ostensible financial antidoping definitely serves as an anticompetitive arrangement in this regard, manipulating sporting competition and further cementing unequal opportunities.

Now, if FCK cannot challenge Real Madrid on talent alone, it needs investment to bridge the financial gap. However, here the second element of FFP kicks in: it is also a discriminatory budget cap in relation to allowed income sources. In order to target this aspect, a closer look at - according to UEFA FFP - non-relevant income is necessary. Income from any of the following sources is not considered to be 'relevant' and does not increase the budget that teams are allowed to spend (simplified; see for details UEFA 2015: 76-81, 87-91):

- non-monetary credits/income, including revaluations and appreciation/depreciation of tangible or intangible fixed assets and inventories,

- income transactions above fair value, for instance, sponsorship arrangements generating revenues in excess of what is standard business practices in the market, similarly supra-market revenues from corporate hospitality tickets and/or use of executive boxes as well as generally from the sale of goods and services,

- donations,

- debt waivers,

- revenues from non-football operations not related to the club (i.e. its brand),

- income in respect of a player for whom the club retains the registration, i.e. if a player (or the transfer rights to a player) who remains on the roster is sold to a third party in order to create immediate revenue. 
As the budget is capped to 'relevant' income, income from these 'non-relevant' sources must not be part of the competition budget. While obvious enforceability problems of these categories are not subject to analysis here, these regulations, in essence, block a number of options for financing investment into talent. It is the economic nature of investment that it is not covered by past and current earnings. Instead, it represents the promise of a share from future earnings, of course, associated with a risk factor. Some of the options regarding this standard business practices are blocked by FFP. Furthermore, financial injections from benefactors are largely blocked as well. The discriminatory element of the FFP budget cap further strengthens the anticompetitive effects of the financial regulation since it effectively blocks several ways for newcomers to finance investment to bridge the financial gap to the incumbents. Thus, it further protects the incumbents' rents and competitive positions from challenges by newcomers.

The second effect is, at least partly, deliberate: combating the (perceived) distortion of competition by financial injections from wealthy benefactors (sometimes labelled sugar daddies in the literature; Lang et al. 2011; Franck 2014; Sass 2016) and/or companies (examples like Paris St. Germain and Manchester City come to mind). And, indeed, buying success by throwing a lot of money from outside of the sport appears to be the prime example of financial doping (Schubert \& Hamil 2017). When it comes to fairness, however, this story can be told in different ways. On the one hand, buying success sounds unfair, on the other hand, foreclosure of the market and no real chance for other teams than the big incumbents to win on a European level sounds unfair as well. RB Leipzig represents an interesting case in question. Leipzig is a traditional football city in Germany with a high number of dedicated fans. The former famous Leipzig football club, Lokomotive Leipzig (and its successors), lost all competitiveness due to long periods of mismanagement. Eventually, Red Bull stepped into the vacuum and created a new team - RasenBall Leipzig - and with a combination of financial injections (outside UEFA's FFP world) and clever management it competed through the ranks and now provides a new challenge to the best football clubs in Germany's Bundesliga. Is it unfair competition - or would it rather have been unfair to, in effect, permanently deter Leipzig's football community from premier-level football experience? After all, 
without the financial injections, it does not seem to be possible to enter the top segment of the market, even in a longer period of time.

The break-even rule of UEFA's FFP regulation serves as an example of an asymmetric and discriminatory budget cap and its anticompetitive effects - the cementing of the competitive order, foreclosure of the premium market segment, and protection of the incumbents' rents and power. Whether they are unwanted and non-anticipated side-effects of pursuing 'good' goals (financial fair play) or whether the incumbents - the big traditional European football clubs - merely sought to prevent a challenge to their powerful position (and implemented a genius market label for their anticompetitive effort by using the financial fair play moniker) is open for discussion and analysis. Different storytelling is possible. This chapter deliberately took the view of possible manipulative effects of financial regulation targeting financial antidoping and, as such, does not provide a balanced analysis of UEFA's FFP (see the literature quoted at the beginning of the section for more comprehensive analyses).

\section{Allocation of Common Revenues as Financial Regulation}

Virtually all professional sports leagues and championships generate common revenues through the marketing of the common product (for instance, use of the league brand for advertising and merchandising, but also for league/championship title sponsorships like the "Monster Energy NASCAR Cup Series", etc.) and, more often than not, through a centralized sale of media rights, in particular traditional and online broadcasting rights. These common revenues are either collected by the market-internal regulator (the competent sports association) itself or by a promoter who is usually in the ownership of either or both the competent sports association and/or the participating teams. ${ }^{7}$ These common revenues need to be distributed among the participating teams and the way this is done represents another avenue

\footnotetext{
${ }^{7}$ Formula One motor racing represents a notable exception where the promoter is an independent investment company seeking to maximize its own profits from the sport. This creates scope for market power abuses by the promoter at the expense of the competing teams (see for details on this case Budzinski \& Müller-Kock 2017).
} 
of financial regulation. Depending on how the common revenues are distributed, different effects on sporting competition result.

Four different types of distribution, which represent economically speaking horizontal allocation mechanisms, can be distinguished (Budzinski \& Müller-Kock 2017: 5):

- equal allocation, i.e. each team receives the same share of the common revenues,

- performance-based allocation, i.e. teams that perform better (higher win or points score, better position in the championship ranking, etc.) receive a higher share of the common revenues than those with worse performances,

- reverse-performance-based allocation, i.e. teams performing better receive a smaller share of the common revenue than those who perform worse, and

- brand-value-based allocation, i.e. teams with a larger fan-base (however this is measured) and/or a higher marketing potential (past success, traditions, etc.) receive higher shares of the common revenues.

Obviously, each category (except of equal allocation) covers a wide range of allocation schemes with different degrees of inequality of the revenue allocation. Of course, these categories can be combined, for instance, a defined percentage of the common revenues may be allocated equally, another percentage performancebased, etc. $^{8}$

Regarding the effects of these allocation mechanisms, it needs to be considered whether the revenues could alternatively be collected individually by the teams, as in the case of broadcasting rights. This is less realistically possible with series/league title sponsorships and brand licensing revenues. In the case of a collective sale of broadcasting and related media rights in team sports leagues, the individual broadcasting rights of the teams regarding their home games are tied into one league-wide bundle, thus completely eroding competition among suppliers of broadcasting rights. This constitutes a hardcore cartel that subsequently acts as a monopolist towards the customers (directly: media companies buying broadcasting

\footnotetext{
${ }^{8}$ For an overview and a discussion of allocation schemes used by selected premier-level professional leagues and championships see Budzinski \& Müller-Kock (2017: 9-13).
} 
rights; indirectly: media consumers ${ }^{9}$ ). While this clearly creates anticompetitive effects like higher prices, limited quantity, and reduced innovation dynamics (for instance, regarding innovative new media coverage), the literature is split on whether (sufficiently strong) countervailing efficiency gains exist that justify this cartel (Késenne 2000, 2009; Falconieri et al. 2004; Gürtler 2007; Noll 2007; Peeters 2011, 2012; Budzinski 2017b). If an individual sale system is possible, opting for a collective system implies that the distribution of financial means among the teams is changed. If the common revenue is inevitable collective in nature, no such benchmark exists. Still, the allocation mechanism affects sporting competition.

If no competitive benchmark exists, a case can be made for equal allocation representing the least distortion of sporting competition. The common product rests on the cooperation of all participants and, thus, all participants equally share its revenues. Another case can be made for brand-value-based allocation. The hypothetical contributions to the value of the common product/brand may not be equal. More popular teams with higher fan-bases may contribute more to it than less popular ones. Thus, defining proxies for brand value (or fan share/popularity) may imperfectly reflect the actual contribution to the generation of the common revenues and, thus, may represent the 'best' allocation. Performance-based and Reverse-performance-based allocations, however, will always include some distortive effects, either advantaging better-performing or lower-performing teams.

If a competitive benchmark like the option of an individual sale system of broadcasting rights exists, distortive effects relate to the allocation that would result from the competitive solution. Then, a brand-value based allocation basically attempts to mimic the competitive benchmark because popularity, fan-base and similar aspects largely determine the value of a team's brand. Current performance is certainly another factor in this. However, teams with popular names (brands) will draw more demand even if they perform worse than no-name teams. Consequently, brand-value based allocation systems have the lowest distortive effects and the closer they mimic the competitive benchmark, the lower is the

\footnotetext{
${ }^{9}$ If, for instance, a TV station spent more for sports broadcasting rights due to the monopoly-like price structure dictated by the cartel, then the whole TV audience will have to contribute to the higher prices by accepting higher pay-TV prices, more advertising in free TV, and less investment in other (also non-sports) programs.
} 
distortion effect. Equal allocation, in contrast, alters the allocation compared to the competitive benchmark and distorts sporting competition in the sense that it disadvantages those teams that could earn higher media revenues in an individual sale system. In other words, in tendency, teams that are very popular with the fans suffer and less popular teams gain. Performance-based allocations also distort sporting competition as they benefit better performing teams irrespective of their popularity with the fans. Thus, bad-performing popular teams lose, whereas good performing low-popularity teams win in financial terms. With reverse-performancebased systems, it is the other way around (bad-performing-low-popularity teams gain, good-performing-high-popularity teams lose). ${ }^{10}$ Keep in mind that from a consumer (fan) welfare perspective disadvantaging popular teams is, ceteris paribus, welfare decreasing since (somewhat tautologously) more people are made happy when popular teams win than when unpopular teams win.

So far, brand-value-based allocation mechanisms appear to be the least distortive ones regarding the implicit financial regulation following from distributing common revenues. Note, however, that mirroring the competitive benchmark very closely makes it harder to justify the existence of a cartel (collective sale system) with its far-reaching anticompetitive effects. On the other hand, economic considerations may motivate the choice of a specific allocation scheme that benefit consumers (fans) and welfare in the end. In other words, common revenues may purposefully be employed to improve sporting competition. Systems of equal allocation and reverse-performance allocation, for instance, follow competitive balance considerations. By advantaging poor-performing teams, their ability to compete with the previously successful ones shall be enhanced and improved, thus, creating closer and more balanced competition. The underlying economic rationale is - somewhat simplified - that more competitive balance increases the uncertainty of outcome, which in turn make the sporting competition more attractive to fans and, consequently, increases demand and fan welfare (Rottenberg 1956; Neale 1964; El-Hodiri \& Quirk 1971; Fort \& Quirk 1995). If this were true, it would represent a justification to deviate from the competitive benchmark. However, since

\footnotetext{
${ }^{10}$ It is quite notable and interesting, how such a perspective contrasts with and goes beyond first glance fairness notions.
} 
the - very substantial - sports economics literature on the demand and welfare effects of competitive balance is very controversial (inter alia, Szymanski \& Késenne 2004; Coates et al. 2014; Humphreys \& Zhou 2015; Budzinski \& Pawlowski 2017; literature overview: Pawlowski \& Nalbantis 2017), the (beneficial) effects of equal or reverse-performance based allocation mechanisms probably needs to be demonstrated case-by-case. Systems of performance-based allocation follow incentive considerations. Financial incentives to perform better add to intrinsic motivation to win. While this may be unnecessary when it comes to meaningful contests like winning the league or the championship, research has shown that it may be necessary to keep competition alive in the midfield, in particular towards the end of a season (Feddersen et al. 2012). Whether these limited additional effects can justify an otherwise anticompetitive cartel (collective sale systems), however, appears to be doubtful.

From an economic perspective, indirect financial regulation through the allocation of common revenues plays an important role when it comes to potential distortive effects of financial regulation. Different allocation schemes affect sporting competition in different ways and to different extents. Since the real world of sports is both manifold and creative in this respect, this chapter can outline some basic considerations and each case must be carefully looked at. This becomes even more important if one considers that the internal allocation of common revenues may well be motivated by power struggles and (individual or collective) anticompetitive intentions instead of goals such as the attractiveness of the sport and fan welfare (Budzinski \& Müller-Kock 2017).

A similar phenomenon is represented by explicit mechanisms to re-allocate individual revenues among the teams. Gate-revenue sharing (inter alia, Késenne 2000), for instance, may imply that each team collects its own revenues at the gate but then pays a share of these revenues into a common pool, which then is reallocated among the teams, usually with the poorer teams (in terms of gate revenues) receiving a net-benefit in financial terms (like the NFL straight-pool sharing arrangement from 2001). So-called luxury taxes implement a (progressive) tax on spending above a defined budget threshold (Dietl et al. 2010). The tax revenues are then distributed among all teams. Thus, it both sets disincentives to 
budget expansion (without a 'hard' budget cap) by making it more expensive and re-allocates financial means within the league. Examples are the luxury tax arrangements of U.S. Major League Baseball (MLB) and the U.S. National Basketball Association (NBA). These instruments of financial regulation have in common that they follow competitive balance considerations and fall into a comparable category as systems of equal allocation and reverse-performance-based allocation as discussed above.

\section{Standards for Sound Financial Management}

Another area of financial regulation is the implementation by mandatory standards for financial management, for instance, accounting standards or audit requirements. Such standards may be set as preconditions to acquire a license to participate in a league, tournament or championship. Many leagues have implemented a licensing system that require teams to submit financial data and business plans and provide external auditing reports according to predefined standards. A more specific example is another element of UEFA's Financial Fair Play Regulations, namely the so-called no overdue payables rule that stipulates that teams participating in UEFA's club competition must not have overdue payments to players or other employees, other football clubs, or to social and tax authorities (UEFA 2015: 28-31).

Standards for sound financial management, if properly defined and enforced, represent an effective instrument against overly expansive and excessively risky financial practices. Furthermore, they can considerably reduce the danger of teams running into insolvency mid-season. Mid-season insolvencies may disturb match operations and endanger the integrity of the competition. At the same time, the standards themselves do not distort sporting competition as long as they follow accepted business practices, are transparent and enforced in a non-discriminatory way, and rely on tools and competences that are available to all the participants. However, costs may be an issue; standards leading to very high costs of accounting and financial management may disadvantage poorer teams. 
Financial guarantees and security deposits are a different story. On the one hand, they may also serve to safeguard economic viability of teams following the logic that sound finances are required to be able to provide the guarantees. Moreover, the deposited money may be used to keep a team going until the end of the season in the case of insolvency and, thus, prevent disruptive effects on match operations. On the other hand, guarantee and deposit requirements may work as entry barriers, in particular if they are excessive. Furthermore, adverse incentives and moral hazard problems may be reinforced when managers know they will be bailed-out by a fund. The German Bundesliga-case of Arminia Bielefeld provides an interesting example (Budzinski \& Müller 2013: 276-278, 280-281). In the second level league (2. Bundesliga), teams could prevent insolvency by receiving financial means from an insurance fund (where all teams had contributed to) but had to pay a price in terms of three penalty points subtracted from the rankings. When Arminia Bielefeld found itself in a sportingly hopeless situation halfway through the 2010-2011 season, it activated the insurance funds - and the penalty points effectively did not hurt them at all (they just remained dead-last).

\section{Conclusion}

Financial regulation in sports is usually discussed in the context of representing an instrument against financial doping. Notwithstanding the merits of this discussion, this chapter takes the opposite perspective and analyses how financial regulation itself may anticompetitively influence and manipulate sporting results. Virtually every regulative financial intervention distorts sporting competition to some extent and creates beneficiaries and losers. Sometimes, the actual winners and losers of financial regulation stand in line with the (legitimate) goals of the regulation. For instance, if the goal is to remedy financial imbalances, then a global and symmetric cap may generate the 'right' winners (low-budget teams) and losers (high-budget teams) - all in relative terms, of course. If the goal is to prevent mid-season insolvencies, a licensing system requiring defined standards for accounting, financial management, and external auditing may represent an adequate instrument. 
However, in many cases the winners and losers of financial regulation do not match with the (announced) goals. This can be due to unintended consequences and sideeffects of regulation - a topic well-known in economic analysis. It can also be a consequence of vested interest of powerful regulatory bodies and/or participants (teams) that are sufficiently powerful to influence the market-internal regulator (lobbyism). Again, politico-economic deficiencies of real-world regulations are another well-known topic in economics. Unfortunately, these lines of reasoning have often been neglected in sports economics analysis so far. ${ }^{11}$ Real-world financial regulation, thus, may distort sporting competition by protecting competitive advantages of powerful teams, cementing the competitive order, deterring market entry by new team talent, serving the regulatory interests of sports associations and/or their officials, and many more.

In this chapter, various types of budget caps (including salary caps and UEFA's financial fair play regulations), different forms of allocation mechanisms of common revenues as well as financial standards are analysed regarding possible and potential anticompetitive effects. Inter alia, asymmetric budget caps, performance-based revenue allocation, and financial guarantees and security deposits are identified to produce anticompetitive effects with a considerable likelihood. Naturally, the analysis relies on stylized regulations and specific examples. It cannot offer a comprehensive discussion of all thinkable variations and combinations of financial regulation. As a consequence, the major implication is to advocate critical case-by-case (theory-driven and empirical) analyses of real-world financial regulation that focuses on the actual effects on competition and does not take the announced goals for granted.

\footnotetext{
${ }^{11}$ But see Keshock et al. (2015) for an interesting story of political economy of sports events and promotion.
} 


\section{References}

Andreff, W. (2007), French Football - A Financial Crisis Rooted in Weak Governance, in: Journal of Sports Economics, Vol. 8 (6), 652-661.

Budzinski, O. (2012), The Institutional Framework for Doing Sports Business: Principles of EU Competition Policy in Sports Markets, in: International Journal of Sport Management and Marketing, Vol. 11 (1-2), 44-72.

Budzinski, O. (2014), The Competition Economics of Financial Fair Play, in: O. Budzinski \& A. Feddersen (eds.), Contemporary Research in Sports Economics: Proceedings of the $5^{\text {th }}$ ESEA Conference, Frankfurt a.M.: Lang, 77-98.

Budzinski, O. (2017a), Budgetungleichgewichte und Budgetregulierung im Profisport: Zur Bedeutung von Rattenrennen, in: T. Pawlowski \& M. Fahrner (eds.), Arbeitsmarkt und Sport - eine ökonomische Betrachtung, Schorndorf: Hofmann, 65-83.

Budzinski, O. (2017b), Competition Policy in Sports Markets, in: Sage Handbook of Sports Economics, Sage, forthcoming.

Budzinski, O. \& Müller, A. (2013), Finanzregulierung und internationale Wettbewerbsfähigkeit: Der Fall Deutsche Bundesliga, in: R. Dewenter, J. Haucap \& C. Kehder (eds.), Wettbewerb und Regulierung in Medien, Politik und Märkten, Baden-Baden: Nomos, 261-290.

Budzinski, O. \& Müller-Kock, A. (2017), Is the Revenue Allocation Scheme of Formula One Motor Racing a Case for European Competition Policy?, in: Contemporary Economic Policy, Vol. 35, forthcoming, doi:10.1111/coep.12247.

Budzinski, O. \& Pannicke, J. (2017), Does Popularity Matter in a TV Song Competition? - Evidence from a National Music Contest, Ilmenau Economics Discussion Papers, Vol. 22, No. 106.

Budzinski, O. \& Pawlowski, T. (2017), The Behavioural Economics of Competitive Balance - Theories, Findings and Implications, in: International Journal of Sport Finance, Vol. 12 (2), 109-122. 
Budzinski, O. \& Szymanski, S. (2015), Are Restrictions of Competition by Sports Associations Horizontal or Vertical in Nature?, in: Journal of Competition Law \& Economics, Vol. 11 (2), 409-429.

Coates, D., Humphreys, B. \& Zhou, L. (2014), Reference-dependent Preferences, Loss Aversion, and Live Game Attendance, in: Economic Inquiry, Vol. 52 (3), 959973.

Dietl, H, Franck, E., Lang, M. \& Rathke, A. (2012), Salary Cap Regulation in Professional Team Sports, in: Contemporary Economic Policy, Vol. 30 (3), $307-$ 319.

Dietl, H., Lang, M. \& Rathke, A. (2011), The Combined Effect of Salary Restrictions and Revenue Sharing in Sports Leagues, in: Economic Inquiry, Vol. 49 (2), 447463.

Dietl, H., Lang, M. \& Werner, S. (2010), The Effect of Luxury Taxes on Competitive Balance, Club Profits, and Social Welfare in Sports Leagues, in: International Journal of Sport Finance, Vol. 5 (1), 41-51.

El-Hodiri, M. \& Quirk, J. (1971), An Economic Model of a Professional Sports League, in: Journal of Political Economy, Vol. 79, 1302-1319.

Falconieri, S., Palomino, F. \& Sákovics, J. (2004), Collective versus Individual Sale of Television Rights in League Sports, in: Journal of the European Economic Association, Vol. 2 (5), 833-862.

Feddersen, A., B. R. Humphreys \& B. P. Soebbing (2012), Contest Incentives in European Football, Working Paper No. 2012-13, University of Alberta.

Fort, R. \& Quirk, J. (1995), Cross-Subsidization, Incentives and Outcomes in Professional Team Sports Leagues, in: Journal of Economic Literature, Vol. 33 (3), 1265-1299.

Franck, E. (2014), Financial Fair Play in European Club Football - What is it All About?, in: International Journal of Sport Finance, Vol. 9 (3), 193-217.

Franck, E. (2016), A Comment on the Newly Revised "2015 Version" of the UEFA Club Licensing and Financial Fair Play Regulations, UZH Business Working Paper, Universität Zürich. 
Gammelsæter, H. \& Senaux, B. (2011), Understanding the Governance of Football across Europe, in: H. Gammelsæter \& B. Senaux (eds.), The Organisation and Governance of Top Football across Europe: An Institutional Perspective, London: Routledge, 268-291.

Gürtler, O. (2007), A Rationale for the Coexistence of Central and Decentral Marketing in Team Sports, in: German Economic Review, Vol. 8 (1), 89-106.

Humphreys, B. R. \& Zhou, L. (2015), The Louis-Schmeling Paradox and the League Standing Effect Reconsidered, in: Journal of Sports Economics, Vol. 16 (8), 835852.

Késenne, S. (2000), Revenue Sharing and Competitive Balance in Professional Team Sports, in: Journal of Sports Economics, Vol. 1 (1), 56-65.

Késenne, S. (2009), The Impact of Pooling and Sharing of Broadcasting Rights in Professional Team Sports, in: International Journal of Sport Finance, Vol. 4 (3), 211-218.

Keshock, C. M., Forester, B. \& Holden, S. (2014), Gridiron Games - A Case Analysis of Turf War Issues and the Economic, Social, Cultural, and Political Incentives for Government Subsidization, in: O. Budzinski \& A. Feddersen (eds.), Contemporary Research in Sports Economics: Proceedings of the $5^{\text {th }}$ ESEA Conference, Frankfurt a.M.: Lang, 231-244.

Könecke, T. \& Schubert, M. (2014), Socio-Economic Doping and Enhancement in Sport: A Case-based Analysis of Dynamics and Structural Similarities, in: O.

Budzinski \& A. Feddersen (eds.), Contemporary Research in Sports Economics: Proceedings of the $5^{\text {th }}$ ESEA Conference, Frankfurt a.M.: Lang, 97-114.

Lang, M., Grossman, M. \& Theiler, P. (2011), The Sugar Daddy's Game: How Wealthy Investors Change Competition in Professional Team Sports, in: Journal of Institutional and Theoretical Economics, Vol. 167 (4), 557-577.

Madden, P. (2015), Welfare Economics of "Financial Fair Play" in a Sports League With Benefactor Owners, in: Journal of Sports Economics, Vol. 16, 159-184. 
Maxcy, J. (2014), The American View on Financial Fair Play, in: O. Budzinski \& A. Feddersen (eds.), Contemporary Research in Sports Economics: Proceedings of the $5^{\text {th }}$ ESEA Conference, Frankfurt a.M.: Lang, 57-73.

Morrow, S. (2011), History, Longevity, and Change: Football in England and Scotland, in: H. Gammelsæter \& B. Senaux (eds.), The Organisation and Governance of Top Football across Europe: An Institutional Perspective, London: Routledge, 46-61.

Neale, W. C. (1964), The Peculiar Economics of Professional Sports: a Contribution to the Theory of the Firm in Sporting Competition and in Market Competition, in: Quarterly Journal of Economics, Vol. 78 (1), 1-14.

Noll, R. G. (2007), Broadcasting and Team Sports, in: Scottish Journal of Political Economy, Vol. 54 (3), 400-421.

Pawlowski, T. \& Nalbantis, G. (2017), Competitive Balance: Measurement and Relevance, in: Handbook of Sports Economics, Sage Publications, forthcoming.

Peeters, T. (2011), Broadcasting Rights and Competitive Balance in European Soccer, in: International Journal of Sport Finance, Vol. 6 (1), 23-39.

Peeters, T. (2012), Media Revenue Sharing as a Coordination Device in Sports Leagues, in: International Journal of Industrial Organization, Vol. 30 (2), 153163.

Peeters, T. \& Szymanski, S. (2014), Financial Fair Play: Winners and Losers on and off the Pitch, in: O. Budzinski \& A. Feddersen (eds.), Contemporary Research in Sports Economics: Proceedings of the $5^{\text {th }}$ ESEA Conference, Frankfurt a.M.: Lang, 17-33.

Peeters, T. \& Szymanski, S. (2015), Financial Fair Play in European Football, in: Economic Policy, Vol. 29, 343-390.

Preuss, H., Haugen, K. \& Schubert, M. (2014), UEFA Financial Fair Play: The Curse of Regulation, in: European Journal of Sport Studies, Vol. 2 (1), 33-51.

Rottenberg, S. (1956), The Baseball Player's Labour Market, in: Journal of Political Economy, Vol. 64 (3), 242-258. 
Sass, M. (2016), Glory Hunters, Sugar Daddies, and Long-Term Competitive Balance under UEFA Financial Fair Play, in: Journal of Sports Economics, Vol. 17 (2), 148158.

Schubert, M. \& Hamil, S. (2017), Financial Doping and Financial Fair Play in European Club Football Competitions, in: Palgrave Handbook on the Economics of Manipulation in Professional Sports, Palgrave, forthcoming.

Schubert, M. \& Könecke, T. (2015), Classical Doping, Financial Doping and Beyond: UEFA's Financial Fair Play as a Policy of Anti-doping, in: International Journal of Sport Policy and Politics, Vol. 7 (1), 63-86.

Schubert, M., Könecke, T. \& Pitthan, H. (2016), The Guardians of European Football - UEFA Financial Fair Play and the Career of Social Problems, in: European Journal for Sport and Society, Vol. 13 (4), 296-324, doi:10.1080/16138171.2016.1248094.

Storm, R. K. \& Nielsen, K. (2012), Soft Budget Constraints in Professional Football, in: European Sport Management Quarterly, Vol. 12, 183-201.

Szymanski, S. (2014), Fair Is Foul: A Critical Analysis of UEFA Financial Fair Play, in: International Journal of Sport Finance, Vol. 9 (3), 218-229.

Szymanski, S. \& Késenne, S. (2004), Competitive Balance and Gate Revenue Sharing in Team Sports, in: The Journal of Industrial Economics, Vol. 52 (1), 165-177.

UEFA. (2015), UEFA Club Licensing and Financial Fair Play Regulations (Edition 2015),

www.uefa.org/MultimediaFiles/Download/Tech/uefaorg/General/02/26/77/91/226 7791_DOWNLOAD.pdf

Vöpel, H. (2011), Do We Really Need Financial Fair Play in European Club Football? An Economic Analysis, in: CESifo DICE Report, Vol. 9 (3), 54-60. 